\title{
Research
}

\section{Assessing the Effectiveness of Payments for Ecosystem Services: an Agent- Based Modeling Approach}

\author{
$\underline{X i a o d o n g ~ C h e n ~}^{1}$, Andrés Viña ${ }^{2}$, Ashton Shortridge ${ }^{3}, \mathrm{Li} \mathrm{An}^{4}$ and Jianguo Liu ${ }^{2}$
}

\begin{abstract}
Payments for ecosystem services (PES) have increasingly been implemented to protect and restore ecosystems worldwide. The effectiveness of conservation investments in PES may differ under alternative policy scenarios and may not be sustainable because of uncertainties in human responses to policies and dynamic human-nature interactions. To assess the impacts of these interactions on the effectiveness of PES programs, we developed a spatially explicit agent-based model: human and natural interactions under policies (HANIP). We used HANIP to study the effectiveness of China's Natural Forest Conservation Program (NFCP) and alternative policy scenarios in a coupled human-nature system, China's Wolong Nature Reserve, where indigenous people's use of fuelwood affects forests. We estimated the effects of the current NFCP, which provides a cash payment, and an alternative payment scenario that provides an electricity payment by comparing forest dynamics under these policies to forest dynamics under a scenario in which no payment is provided. In 2007, there were $337 \mathrm{~km}^{2}$ of forests in the study area of $515 \mathrm{~km}^{2}$. Under the baseline projection in which no payment is provided, the forest area is expected to be $234 \mathrm{~km}^{2}$ in 2030 . Under the current NFCP, there are likely to be $379 \mathrm{~km}^{2}$ of forests in 2030 , or an increase of $145 \mathrm{~km}^{2}$ of forests to the baseline projection. If the cash payment is replaced with an electricity payment, there are likely to be $435 \mathrm{~km}^{2}$ of forests in 2030, or an increase of $201 \mathrm{~km}^{2}$ of forests to the baseline projection. However, the effectiveness of the NFCP may be threatened by the behavior of newly formed households if they are not included in the payment scheme. In addition, the effects of socio-demographic factors on forests will also differ under different policy scenarios. Human and natural interactions under policies (HANIP) and its modeling framework may also be used to assess the effectiveness of many other PES programs around the world.
\end{abstract}

Key Words: agent-based modeling; conservation investments; coupled human-nature systems; fuelwood; Natural Forest Conservation Program; payments for ecosystem services

\section{INTRODUCTION}

Humans have exerted substantial and growing impacts on the Earth's ecosystems (Millennium Ecosystem Assessment 2005) resulting in biodiversity loss and ecosystem degradation worldwide (Wackernagel et al. 2002, Luck et al. 2004). Human alteration of Earth is not limited to human-dominated landscapes, but is also common in many protected areas around the world (Liu et al. 2001, Curran et al. 2004). To counter this trend, conservation efforts, including payments for ecosystem services (PES), have been undertaken by governments, private sectors, and conservation-oriented nongovernment organizations (OECD 1997, Ferraro and Kiss 2002). Payments for ecosystem services programs provide incentives directly to ecosystem services providers to undertake actions for desired environmental benefits; an approach that promises improved effectiveness of conservation investments (Ferraro and Kiss 2002, Wunder 2007). Because PES programs aim at reducing human impacts through shaping human actions (Smith 1995, Zbinden and Lee 2005, Wunder 2008), their effectiveness depends on program design as well as human actions in response to these programs.

The effectiveness of conservation investments has been a great concern to conservation practitioners (James et al. 1999, Ferraro and Kiss 2002). Previous studies suggested that PES programs have reduced soil and wind erosions (Osborn et al. 1993), restored deteriorated ecosystems (Dunn et al. 1993, Sierra and Russman 2006), and provided habitat to wildlife (Johnson and Schwartz 1993, McMaster and Davis 2001, Asquith et al. 2008). Most evaluations of the effectiveness of conservation investments rely on comparisons of aggregated environmental outcomes with and without conservation interventions (Salafsky and Margoluis 1999, Cullen et al. 2001, Viña et al. 2007), without taking heterogeneous human decision making into consideration. A few cost-effective analyses of conservation investments that incorporate individual-level characteristics (Siikamäki and Layton 2007, Chen et al. 2010) often neglect how dynamics of these characteristics interact and result in macrolevel environmental outcomes. These knowledge gaps are largely because of a lack of integration of dynamic human-nature interactions into the evaluation of conservation investments.

Although the importance of human-nature interactions has long been recognized (Foley et al. 2005, MEA 2005), complex processes and emergent patterns in these interactions have not been well understood. This is largely because social and ecological sciences have traditionally developed separately (Rosa and Dietz 1998). Humans and nature interact in coupled human and natural systems (CHANS; Liu et al. 2007a, b). Concepts similar to CHANS include social-ecological systems (Ostrom 2009) and coupled human-environment systems (Turner et al. 2007). From the perspective of systems theory (Von Bertalanffy 1968, Warren et al. 1998), complexity features in human-nature interactions can be demonstrated in many forms, including heterogeneous components, nonlinear relationships, stochasticity, uncertainty, and multiple interactions, e.g., learning and feedback, among different components (Arthur 1999, Axelrod and Cohen 1999, Crawford et al. 2005). Previous studies have revealed the importance of complexity features in human-nature interactions (An et al. 2005, Malanson et al. 2006, Liu et al. 2007a, Walsh et al. 2008). The understanding of complex human-nature

\footnotetext{
${ }^{1}$ Department of Geography, University of North Carolina at Chapel Hill, ${ }^{2}$ Center for Systems Integration and Sustainability, Department of Fisheries and Wildlife, Michigan State University, ${ }^{3}$ Department of Geography, Michigan State University, ${ }^{4}$ Department of Geography, San Diego State University
} 
interactions relies on the integration of cross-scale and crossdisciplinary data and methods for which traditional approaches are often inadequate (Parker et al. 2003, An et al. 2005, Liu et al. 2013).

Originating in artificial intelligence and paralleling individualbased modeling in ecology, agent-based modeling (ABM) is a bottom-up method that simulates actions of individual 'agents,' e.g., persons or households, and their interactions with the environment to produce aggregated macrolevel patterns and processes (Parker et al. 2003, An et al. 2005). Agents have autonomous actions and are capable of interacting with other agents and the environment. Because of these features, ABM has been successfully applied in ecological studies, such as those for land use/cover changes, to understand driving processes of environmental changes and explore plausible future trajectories and policy implications (Deadman et al. 2004, Matthews et al. 2007). Agent-based modeling is also an excellent tool for understanding responses of human activities to institutional transitions and the resulting macrolevel environmental and social outcomes (Manson and Evans 2007, Chen et al. 2012a).

We demonstrate the evaluation of conservation investments in PES by integrating environmental outcomes with human actions in a spatially explicit agent-based model, human and natural interactions under policies (HANIP). Our model was built through integration of cross-disciplinary methods and parameterized with cross-scale data, in which household survey and population census data were used to characterize human actions and model dynamics in population and households, and satellite imagery was used to model dynamics in environmental outcomes. Through simulation experiments, HANIP can be used to evaluate the effectiveness of a PES program and possible scenarios by comparing environmental outcomes under alternative policy interventions. In addition, HANIP can be used to explore dynamics in the effectiveness of a PES program because of uncertainties in human responses to policy interventions and complex human-nature interactions. Human and natural interactions under policies (HANIP) was parameterized to evaluate the effectiveness of China's Natural Forest Conservation Program (NFCP) and alternative policy scenarios in Wolong Nature Reserve in which incentives are provided for local residents to reduce fuelwood use that affects natural forests.

\section{China's Natural Forest Conservation Program}

Over the past three decades, China's economy has grown faster than that of any other major nation, fueling unprecedented ecosystem degradation that has caused devastating socioeconomic impacts (Liu and Raven 2010). For instance, the severe droughts in 1997 and the major floods in 1998 were partially the result of excessive deforestation (World Bank 2001). To mitigate the impacts of its degraded ecosystems, China has been implementing several PES programs (Liu and Diamond 2005, Liu 2010). Among these programs is the Natural Forest Conservation Program (NFCP), also referred to as the Natural Forest Protection Program, which is one of the largest PES programs in the world (Xu et al. 2006a, Liu et al. 2008). The NFCP conserves natural forests through logging bans and afforestation by providing incentives to forest enterprises and rural communities (Xu et al. 2006b).

The NFCP started as a pilot program in 1998 and has been fully implemented since 2001. The aims of the NFCP are to: (1) protect and restore natural forests in the upper reaches of the Yangtze river basin and the middle-upper reaches of the Yellow river basin and through reduction in harvesting elsewhere; (2) construct plantation forests through aerial seeding and artificial planting to increase the capacity for timber harvesting from plantation forests; and (3) create alternative employment for traditional forest enterprises (Zuo 2002, Liu et al. 2008). The NFCP has been implemented through such means as logging bans and shifting forest enterprises from timber harvesting to tree plantations and forest management. Creators of this program planned to reduce timber harvests in natural forests from 32 million $\mathrm{m}^{3}$ in 1997 to 12 million $\mathrm{m}^{3}$ in 2003 and afforest 31 million ha by 2010 . Conservation payments to stakeholders are provided for 10 years. By the end of 2005, about 61 billion yuan had been invested through the NFCP (Liu et al. 2008). Specific implementations of the NFCP in different regions in China are different. The NFCP has been recognized as an especially important tool for avoiding deforestation and restoring degraded ecosystems in many biologically significant regions such as nature reserves (Loucks et al. 2001, Liu et al. 2008).

\section{METHODS}

\section{Study area}

Wolong Nature Reserve (Fig. 1) is located in China's southwest Sichuan province and within one of the top 25 global biodiversity hotspots (Myers et al. 2000). It is one of the largest reserves for the protection of the world-famous endangered giant pandas (Ailuropoda melanoleuca). In addition to providing habitat for about $10 \%$ of wild giant pandas and more than 6000 plant and animal species, Wolong is also home to about 4500 indigenous

Fig. 1. Locations and elevations of Wolong Nature Reserve and indigenous households in the reserve.

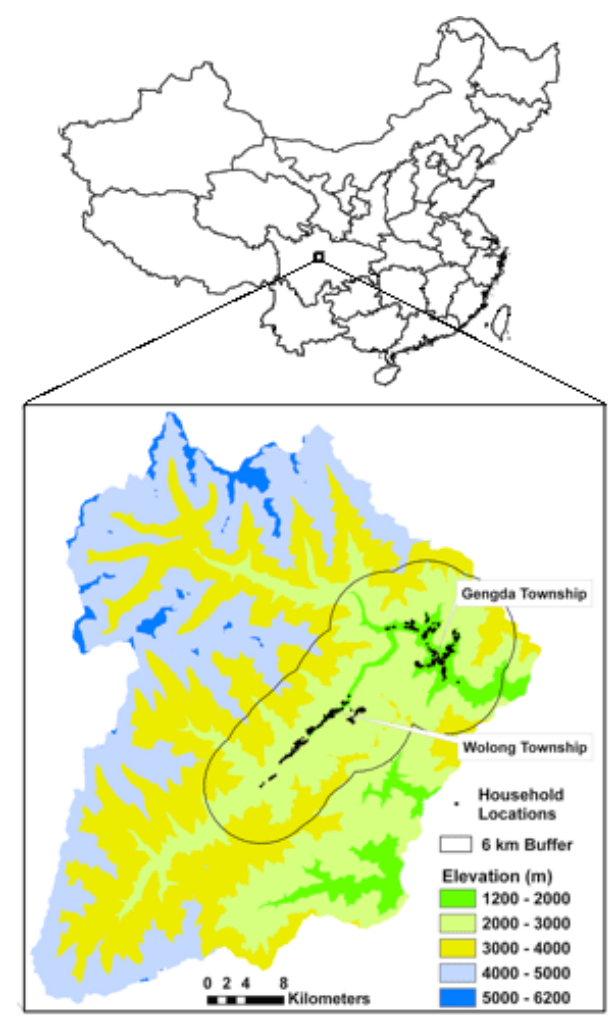


Fig. 2. Conceptual framework of the model.

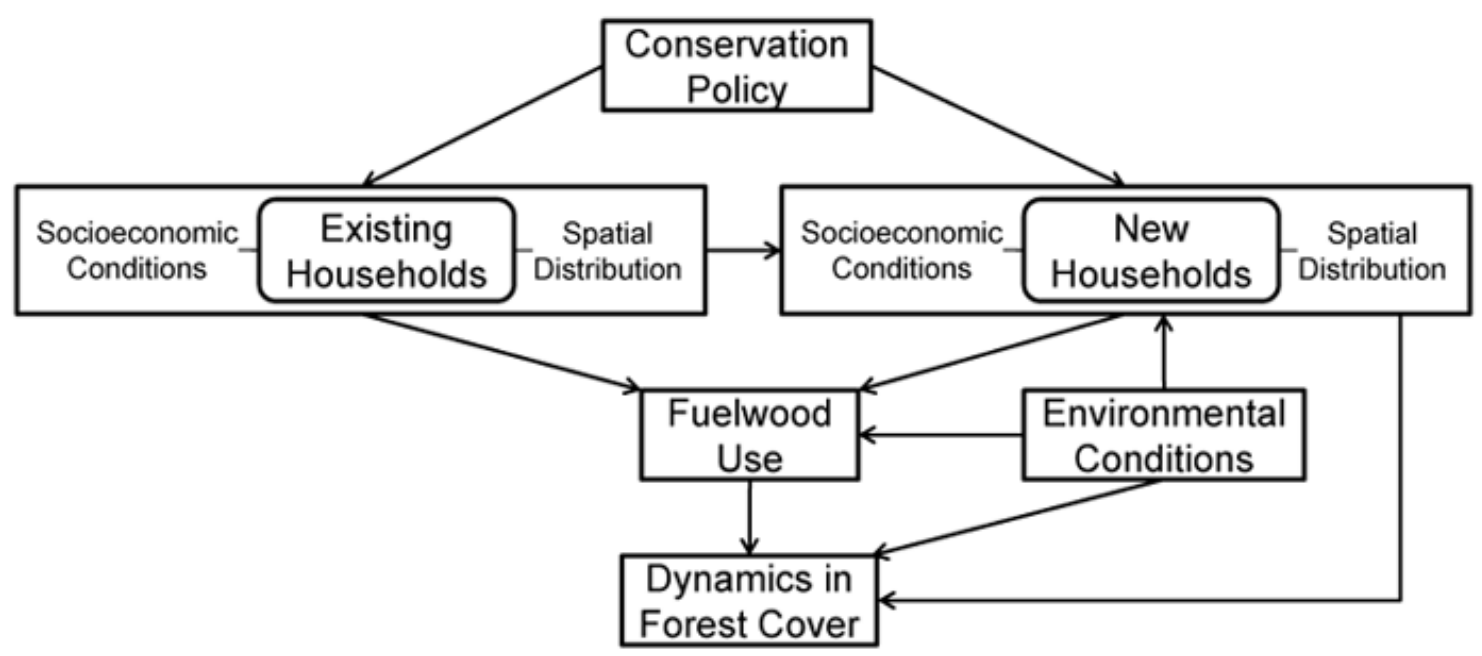

human residents (Liu et al. 2007a). People in the reserve engage in diverse economic activities such as fuelwood collection, deforestation for agricultural land, grazing, and support for tourism (He et al. 2008). Previous studies in this reserve have demonstrated rapid degradation in panda habitat because of these human impacts, including fuelwood collection and deforestation for agricultural land (An et al. 2005, Viña et al. 2007). Moreover, the rapidly growing human population and the even more rapid rise in the number of households have produced increasing human impacts on the ecosystem in the reserve (Liu et al. 2003).

Although enormous amounts of time and effort are needed for fuelwood collection because of the extremely rugged terrain and increasing difficulty of fuelwood collection as a result of the reduction in forested areas (He et al. 2009), indigenous people in the reserve still rely on fuelwood for much of their cooking and heating energy requirements. The reserve administration had limited the amount and location of fuelwood collection since 1984 (Wolong Nature Reserve 2000); however, it was difficult for the administration to monitor and enforce collection regulations because of the complex terrain and broad spatial extent of the reserve (Fig. 1). Electricity, as an alternative to fuelwood, was available in Wolong, but it had been used mainly for lighting and some electronic appliances, e.g., TV, because electricity was expensive for residents, and the voltage and stability of electricity were not reliable (An et al. 2002). To encourage the use of electricity as a replacement for fuelwood, the electricity networks in Wolong were reconstructed by the government in 2001, and this has resulted in greatly improved voltage and stability for all the residents within the reserve. However, these conservation policies and efforts were not effective without conservation payments to indigenous people or substantial investments in monitoring (Liu et al. 2007a).

The NFCP enrollment took place in Wolong Nature Reserve in 2001. All households that existed in 2001 were enrolled in the
NFCP for 10 years. No additional enrollment in NFCP has been offered since 2001, and new households, i.e., households formed after 2001, were not included in the program. Under the NFCP contract, every household or group of 2-16 households have been allocated a natural forest parcel, which is monitored to prevent illegal harvesting (Yang et al. 2013). Each participating household is provided an annual payment of about 850 yuan, which comprised $14 \%$ of the average 2001 annual income of Wolong households ( $\mathrm{He}$ 2008). If illegal timber harvesting is found in a forest parcel, the monitoring households will lose part or all of their NFCP payment for the year, depending on the degree of harvest activity in the parcel. Illegal harvesters, if caught, lose their NFCP contracts. Participating households are encouraged to use the payment to purchase electricity to replace fuelwood.

\section{Model summary}

The conceptual framework of HANIP (Fig. 2) was implemented in three submodels. In the demographic submodel, human dynamics, including population and household processes, were modeled by simulating individual people's life histories. Young adults may form new households after they get married, and newly formed households are geographically distributed around their parental households, i.e., households in which new households are separated from, depending on the environmental conditions. Household fuelwood use was modeled in the policy submodel (Fig. 2) as functions of both household characteristics, local environmental conditions, and conservation policy. Both household fuelwood use and deforestation for housing and farming of new households affect dynamics in forest cover, which was modeled in the landscape submodel (Fig. 2). Changes in forest cover also depend on environmental conditions. We focused on a $6-\mathrm{km}$ buffer region surrounding all households in the reserve. We employed this buffer size because almost all fuelwood collection and deforestation for housing and farming occurred within $6 \mathrm{~km}$ of the households (Linderman et al. 2005). This region covered 515 $\mathrm{km}^{2}$ (Fig. 1), including $337 \mathrm{~km}^{2}$ of forests in 2007 (Viña et al. 2011). Comparisons of cumulative forest area under different policy 
scenarios allowed detection of the effectiveness of conservation investments. Human and natural interactions under policies (HANIP) was developed using the Java programming language (JDK 1.4.2, Sun Microsystems) and was parameterized using data from different sources, including population and agricultural censuses, household interviews, and environmental conditions.

We used an agent-based modeling approach because it allowed us to take the heterogeneous human and environmental characteristics into consideration. Agents are capable of 'sensing' other agents' conditions when making decisions such as getting married and creating new households. Dynamics in agents' characteristics lead to dynamics in human activities, which result in changes in the environment. Dynamic environmental conditions also affect human decisions such as the location of new households. Simulation of interactions between human agents and the environment on aggregate can produce emergent properties such as the nonlinear effects of conservation policies. In addition, agent-based modeling allowed us to incorporate many stochastic processes in human-environment interactions. Our agent-based model, HANIP, was used as a 'laboratory' for exploring the effects of alternative policy scenarios.

\section{Demographic submodel}

We obtained characteristics of every household in the reserve and of each of its corresponding household members from three government census datasets: the 1996 agricultural census, 4053 residents in 892 households, the 2000 population census, 4375 residents in 969 households, and the 2006 household registration, 4504 residents in 1197 households. These characteristics included age, gender, and marital status of each household member, kinship relations among household members, and amount of cropland of each household. In addition, we measured the geographic locations and elevations of all households in the summer of 2006 using differentially corrected Global Positioning System (GPS) receivers.

Our demographic submodel was largely adopted from previous studies in the reserve (An et al. 2001, 2003, 2005). Population dynamics were modeled by simulating individual people's life histories at one-year increments. Major events of person agents included birth, out-migration by students moving to colleges and technical schools, marriage, migration into and out of the reserve through marriage, aging by one year increments, and death. We only considered migration through marriage and education because other types of permanent migration have been rare because of the hukou system of permanent residency (An and Liu 2010). Events of person agents were modeled as stochastic processes based on person agent attributes that included age, gender, kinship relation, and marital status (An et al. 2005). Attributes of household agents included location and elevation of households, amount of cropland, household size, and presence of senior people, i.e., > 60 years old. When young adults get married, a new household may be formed, which was modeled as a stochastic process depending on the gender of the young adult, whether the young adult had siblings, the age of the young adult compared to siblings, and the young adult's intention of forming a new household. The intention of young adults to form new households was modeled using a random probability, separate home intention, which represents the probability for young adults to form a new household when they get married. The default value of separate home intention was 0.42 (An et al. 2005). Major events of household agents also included change in household size, which depended on the life history of each household member, and the dissolution of a household, which occurred when there were no members left in the household.

Based on information from existing households (An et al. 2005), newly formed households were stochastically located in areas with slopes $<37$ degrees. A parameter, max new-parental households distance, was used to specify the maximum possible distance between a new household and its parental household, with a default value of $800 \mathrm{~m}$. The distance between each new household and its parental household was a stochastic value between zero and the max new-parental households distance. On the basis of previous studies in this area (An et al. 2005), farmlands developed by new households were located immediately around their corresponding households. Therefore, we modeled the development of farmlands by new households indirectly in the way that farmland and buildings of each household were located within the same pixel, $90 \mathrm{~m}$ by $90 \mathrm{~m}$, in HANIP. A $90 \mathrm{~m}$ by $90 \mathrm{~m}$ pixel size was chosen based on the availability of environmental data and to maintain manageable computational complexity. We updated the young adult's probability of moving out of the reserve by going to college and technical schools, which was modeled using a random probability, college/technical school entrance rate, based on the 2006 household registration data. The college/ technical school entrance rate represents the probability of eligible young adults, most of them between 16 and 20 years old, who go to college and technical school each year, and the default value was 0.055 .

\section{Policy submodel}

We used three policy scenarios in HANIP: no payment, cash payment under the current NFCP, and electricity payment that substitutes cash payment at the same cost. To understand household fuelwood use patterns under the cash payment and electricity payment, we randomly chose 321 households from a total of 1197 households for in-person interviews, resulting in 305 valid interviews and a 95\% response rate, in the summer of 2006 . We chose household heads or their spouses as interviewees because they were usually the decision makers of household affairs. We asked about the average amount of daily fuelwood consumption in the previous year (2005) for both the winter season when more fuelwood was consumed and the summer season when less fuelwood was consumed. Household fuelwood use was measured as a summation of daily consumption across the year. We also asked about the amount of fuelwood that each household would demand if the cash payment of the NFCP $(850$ yuan) was substituted with electricity payment at the price in 2006 $\left(0.18\right.$ yuan $\left./ \mathrm{kW}^{*} \mathrm{~h}\right)$, which leads to an electricity payment of 14 $\mathrm{kW}^{*} \mathrm{~h}$ per day.

Because all households were enrolled in the NFCP in 2001, we did not have a control group of households in which the NFCP was not implemented. Therefore, accurate evaluation of the effect of the NFCP on fuelwood use was not feasible. Under the nopayment scenario, household fuelwood use was assumed to follow the fuelwood use pattern prior to the NFCP because there was a drastic reduction in fuelwood use from 1999 to 2005 and an abrupt change in forest cover from rapid deforestation to rapid forest regeneration since 2001. The NFCP was the major reason for this 
change (Viña et al. 2011). Household fuelwood use pattern prior to the NFCP was measured according to a previous study that modeled fuelwood use on the basis of household size, presence or absence of senior people in the household, and farmland area (An et al. 2001). Prior to the NFCP, the mean household fuelwood use per year was $15 \mathrm{~m}^{3}$. Although many other factors, for which we do not have data for the whole population, may have also affected fuelwood use under the no-payment scenario, these factors are also likely to have similar effects on fuelwood use under the cash payment and the electricity payment, therefore less likely to have a major impact on the differences in environmental outcomes among different policy scenarios.

Interviews with 305 households showed an average household fuelwood consumption of approximately $9 \mathrm{~m}^{3}$ per year under the current NFCP with cash payment. Compared to fuelwood use in 1999 (An et al. 2001), there was approximately a 40\% reduction in fuelwood use. Major human activities that involve the use of fuelwood or electricity included cooking human food, and heating and cooking pig fodder. In 1999, only a small proportion of households used electricity for these activities (An et al. 2002). In $2005,44.3 \%$ of households used electricity exclusively for cooking human food, and $54.4 \%$ of households used both electricity and fuelwood for cooking human food. For heating, 23.9\% of households used electricity exclusively, and $52.1 \%$ of households used both electricity and fuelwood. Almost all households relied on fuelwood for cooking pig fodder in 2005.

The total electricity expenses of households accounted for only $73 \%$ of the NFCP payment on average in 2006, suggesting that only part of the conservation payment was used to replace fuelwood. If the cash payment of the NFCP was substituted with an electricity payment of $14 \mathrm{~kW}^{*} \mathrm{~h}$ per day, the average household fuelwood demand would be $5.9 \mathrm{~m}^{3}$ per year. We pooled household fuelwood consumption under the cash payment and household fuelwood demand under the electricity payment, and used pooled ordinary least squares (OLS) to estimate the effects of electricity payment and household characteristics available from all the households in the reserve. Because of the correlation in fuelwood use under the cash payment and under the electricity payment for the same households, pooling household fuelwood use under different payment scenarios may result in heteroscedasticity in the regression. We used Huber's variance correction to obtain heteroscedasticity-robust standard errors (Wooldridge 2002).

Household fuelwood use was significantly positively correlated to household size because more people in a household usually required more fuelwood for cooking and heating (Table 1). The farmland area of households was significantly positively correlated to household fuelwood use because households with more cropland usually grew more crops to feed more pigs, and fuelwood for cooking pig fodder was an important part of household fuelwood use. Elevation of households was also significantly positively correlated to fuelwood use because households at higher elevations usually needed more fuelwood for heating in winters than those at lower elevations because of differences in microclimate. If the cash payment was substituted with electricity payment, household fuelwood use would be reduced by $3.1 \mathrm{~m}^{3}$ per year on average (Table 1). We then applied the regression (Table 1) to estimate the fuelwood consumption of all the households in the reserve under the cash payment and the electricity payment.
Table 1. Pooled Ordinary Least Squares of fuelwood use pattern (m3).

\begin{tabular}{lcc}
\hline \hline Independent variables & Parameters & Robust SE \\
\hline Household size & $0.441^{*}$ & 0.241 \\
Farmland (ha) & $5.742^{* *}$ & 2.522 \\
Elevation (100 m) & $0.746^{* * * *}$ & 0.154 \\
Electricity payment (dummy) & $-3.097^{* * * *}$ & 0.267 \\
Constant & $-8.164^{* * *}$ & 3.074 \\
R-squared & 0.12 & \\
\hline
\end{tabular}

Observations: 610 .

Significance: $* p<=0.1 ; * * p<=0.05 ; * * * p<=0.01 ; * * * * p<=$ 0.001 .

In the policy submodel, the magnitude of reduction in fuelwood use by substituting the cash payment with the electricity payment was modeled using a random parameter, electricity payment effect, with a default mean value of $3.1 \mathrm{~m}^{3}$ per year (Table 1). Electricity payment was more efficient than cash payment in reducing fuelwood use because all of the electricity payment would be used for energy requirements to reduce fuelwood use whereas not all the cash payment may be used for electricity. In contrast to An et al. (2001), availability of senior people in the households was not significantly correlated to fuelwood use. This is probably because extra fuelwood use by seniors for heating before the NFCP was a relatively easy part in the reduction of fuelwood use under the NFCP. Although new households were not included in the NFCP, we did not find significantly more fuelwood use in these new households compared to other households. In addition to the increased monitoring efforts by households who participated in the NFCP, similar fuelwood use between new households and other households may also be because fuelwood use of new households can be substantially influenced by the fuelwood use pattern of most of the households in the reserve who are enrolled in the NFCP, including their parental households. This type of phenomenon of normative impact has been found in previous studies in this area and elsewhere (Goldstein et al. 2008, Chen et al. 2009). Moreover, these new households had smaller household sizes $($ mean $=2.8)$ than those which were enrolled in the NFCP (mean = 4.0), leading to comparable fuelwood use even though new households were not included in the NFCP.

Because the number of new households increases and the size of new households changes, their fuelwood use pattern may be uncertain if they continue to be excluded from the NFCP. We explored this uncertainty by parameterizing the fuelwood use of new households under three different scenarios: all the new households follow the fuelwood use pattern under the current NFCP; half of the new households follow the fuelwood use pattern prior to the NFCP, i.e., no payment, and the other half of the new households follow the fuelwood use pattern under the current NFCP; and all of new households follow the fuelwood use pattern prior to the NFCP.

\section{Landscape submodel}

The dynamics of forest cover in Wolong were obtained from the classification of remotely sensed imagery (Landsat Thematic Mapper) acquired on June 26, 1994, June 13, 2001, and September 18, 2007. We used an unsupervised classification based on the ISODATA technique, which is an iterative process for 
nonhierarchical pixel classification (Jensen 1996). A maximum of 1000 iterations were used for classification and produced an output of 100 spectral classes. We then applied a postclassification sorting method and merged the 100 spectral classes into four information classes: forest, nonforest, clouds, and cloud shadows through a combination of visual interpretation of these images and information on land cover obtained from high spatial resolution multispectral imagery, i.e., four IKONOS multispectral scenes ( $4 \times 4 \mathrm{~m} /$ pixel), acquired on August 31, October 3, and November 8 and 16 of 2000, respectively, and a Quickbird multispectral scene $(2.4 \times 2.4 \mathrm{~m} /$ pixel) acquired on November 23, 2007. A few areas under cloud and cloud shadows were excluded from further analysis. The accuracy of classification was assessed using ground truth points collected during the summers of 1998 (209 points), 2000 (83 points), 2001 (83 points), and 2007 (593 points) that were measured using GPS receivers in real-time and differentially corrected since 2000 . The overall accuracies of classified forest distributions were $79.2 \%, 78.2 \%$, and $82.6 \%$ for the 1994, 2001, and 2007 imagery, respectively.

From 1994 to 2001, there was $20.1 \%$ forest loss and $12.0 \%$ forest recovery, resulting in $8.6 \%$ net deforestation. From 2001 to 2007 , there was $12.4 \%$ forest loss and $22.7 \%$ forest recovery, resulting in $10.3 \%$ net forest regeneration. To analyze forest dynamics, i.e., forest loss and forest recovery, at pixel level, we randomly selected 4500 pixels, in which two-thirds of the data, i.e., 3000 pixels, were used for model calibration, and one-third of the data were used for model validation. The 3000 pixels that were used for model calibration corresponded to 1982 forest pixels and 1018 nonforest pixels in 1994, and 1797 forest pixels and 1203 nonforest pixels in 2001 (Table 2). We compared these 3000 pixels between 1994 and 2001 to characterize forest loss and recovery during this period. Similarly, to characterize forest loss and recovery in the 2001-2007 period, we compared these pixels between 2001 and 2007. We pooled forest pixels in 1994 and 2001 for a total of 3779 forest pixels, and pooled nonforest pixels in 1994 and 2001 for a total of 2221 nonforest pixels. We modeled forest loss in 1994-2001 and 2001-2007 with the pooled forest pixels and forest recovery in 1994-2001 and 2001-2007 with the pooled nonforest pixels (Table 2) using two logistic regression models. We corrected for dependencies between pixels that represented both 1994-2001 and 2001-2007 periods with Huber's variance correction (Wooldridge 2002).

Table 2. Summary of data for the calibration and validation of forest loss and recovery models.

\begin{tabular}{lccccc}
\hline \hline $\begin{array}{l}\text { Year of } \\
\text { data }\end{array}$ & \multicolumn{2}{c}{$\begin{array}{c}\text { Model calibration (3000 } \\
\text { pixels) }\end{array}$} & & \multicolumn{2}{c}{$\begin{array}{c}\text { Model validation (1500 } \\
\text { pixels) }\end{array}$} \\
\cline { 2 - 3 } \cline { 5 - 6 } & $\begin{array}{c}\text { Forest } \\
\text { pixels }\end{array}$ & $\begin{array}{c}\text { Nonforest } \\
\text { pixels }\end{array}$ & & $\begin{array}{c}\text { Forest } \\
\text { pixels }\end{array}$ & $\begin{array}{c}\text { Nonforest } \\
\text { pixels }\end{array}$ \\
\hline 1994 & 1982 & 1018 & & 976 & 524 \\
2001 & 1797 & 1203 & & 892 & 608 \\
Pooled & 3779 & 2221 & & 1868 & 1132 \\
1994 and & & & & & \\
2001 & & & & & \\
\hline
\end{tabular}

In the logistic regression models, we used biophysical variables that were used in previous studies of forest dynamics (Geoghegan et al. 2001, Nagendra et al. 2003, Viña et al. 2011). These variables included elevation, slope, aspect, which was converted into soil moisture classes (Parker 1982), and distance to the forest edge (Tables 3, 4). In addition, we used a fuelwood impact variable that was measured as:

$$
\begin{aligned}
& \text { fuelwood_impact }_{i}= \\
& \qquad \sum_{\text {distance }_{i j}<6 \mathrm{~km}} \text { fuelwood_consumption }_{j} / \text { distance }_{i j}
\end{aligned}
$$

in which fuelwood_impact ${ }_{i}$ represents fuelwood impact on the $i$ th

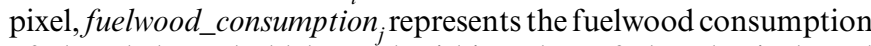
of the $j$ th household located within $6 \mathrm{~km}$ of the $i$ th pixel, and distance $_{i j}$ represents the distance between the $i$ th pixel and the $j$ th household. The fuelwood impact is, therefore, an inverse-distance weighted aggregation of the fuelwood consumption of all eligible households, i.e., households within 6-km buffer from the pixel, on each pixel. This metric reflects the fact that forests closer to households are more likely to be degraded or logged (He et al. 2009). We also used a total fuelwood variable that measured the total amount of fuelwood consumption by all households in the reserve as an explanatory variable (Tables 3,4). Fuelwood consumption prior to the NFCP (An et al. 2001) was applied to those pixels that were used to characterize forest loss and recovery between 1994 and 2001, and fuelwood consumption under the current NFCP (Table 1) was applied to those pixels that were used to characterize forest loss and recovery between 2001 and 2007.

Table 3. Pooled logit estimation of forest loss.

\begin{tabular}{lcc}
\hline \hline Independent variables & Parameters & Robust SE \\
\hline Elevation $(100 \mathrm{~m})$ & -0.008 & 0.014 \\
Slope (degree) & 0.001 & 0.006 \\
Aspect (Parker scale) & $-0.054^{* * *}$ & 0.008 \\
Distance to forest edge $(\mathrm{m})$ & $-0.019^{* * *}$ & 0.001 \\
Fuelwood impact $\left(\mathrm{m}^{3} / \mathrm{m}\right)$ & $0.031^{* * *}$ & 0.008 \\
Total fuelwood $\left(1000 \mathrm{~m}^{3}\right)$ & $0.020^{* * *}$ & 0.003 \\
Constant & $-1.667^{* * *}$ & 0.502 \\
Chi-square & $347.46^{* * *}$ & \\
\hline
\end{tabular}

Observations: 3779 .

Significance: $* * * p<=0.001$.

Table 4. Pooled logit estimation of forest recovery.

\begin{tabular}{lcc}
\hline \hline Independent variables & Parameters & Robust SE \\
\hline Elevation & -0.008 & 0.011 \\
Slope & -0.009 & 0.006 \\
Aspect & $0.064^{* * *}$ & 0.010 \\
Distance to forest edge & $-0.014^{* * *}$ & 0.001 \\
Fuelwood impact & -0.009 & 0.008 \\
Total fuelwood & $-0.023^{* * *}$ & 0.003 \\
Constant & $1.792^{* * *}$ & 0.399 \\
Chi-square & $263.70^{* * *}$ & \\
\hline
\end{tabular}

Observations: 2221

Significance: $* * * p<=0.001$. 
We then applied the logistic regression models for forest loss and recovery to all the pixels in the landscape submodel. The duration of forest dynamics between 1994 and 2001 was seven years. Because the NFCP enrollment took place in 2001, we assumed the deforestation trend before the NFCP was due to human impacts in the first six years (1994-2000). The duration of forest dynamics between 2001 and 2007 was also six years. Because HANIP was built on a yearly basis, we approximated the annual dynamics in each pixel by dividing the estimated probabilities of forest loss and forest recovery from logistic regression models (Tables 3,4 ) by six years. Although the values of topographic variables, i.e., elevation, slope, and aspect, of each pixel do not change over time in HANIP, distance to forest edge changes yearly as forest cover changes. In addition, both fuelwood impact and total fuelwood variables (Tables 3, 4) change in each year depending on population and households, which change annually. We estimated the probability of forest loss for each forest pixel and the probability of forest recovery for each nonforest pixel in each year in HANIP and determined annual forest dynamics of each pixel with a Bernoulli trial. The rate parameters of the Bernoulli distributions were the probability of forest loss or forest recovery.

\section{Model validation and sensitivity analysis}

Because of limits in data availability, the demographic submodel and the landscape submodel started in different years. For model validation, the demographic submodel started in 2000 using 2000 population census data, and the landscape submodel started in 2001 using 2001 land-cover data. Our model validation refers to the comparison of simulation results with empirical data. We evaluated the landscape submodel by testing regression models for forest loss and forest recovery using a receiver operating characteristic (ROC) curve (Hanley and Mcneil 1982). ROC curve demonstrates the performance of a binary classifier as its discrimination threshold is varied. The ROC curve is a plot of the sensitivity values, i.e., true positive fraction, versus their equivalent 1 -specificity values, i.e., false positive fraction, for all possible probability thresholds. The area under the ROC curve (AUC) is a measure of model accuracy, with AUC values ranging from 0 to 1 , where a score of 1 indicates perfect discrimination, a score of 0.5 implies a classification that is not better than random, and a score that is lower than 0.5 implies a worse than random classification. We used the validation data set (Table 2) for deriving the AUC values to evaluate the performance of logistic regression models for classifying forest loss and forest recovery. We also compared the observed forest area in 2007 to the mean of predicted forest areas in 2007 from 30 simulation runs.

For the demographic submodel, we compared the observed population size and the number of households in 2006 to the simulation results. Although validation of the effects of policy scenarios on forest area was not feasible, measurement of the impact of the current cash payment relied on the validation of the landscape submodel and the fuelwood use pattern under the scenario in which no payment was provided and validated in a previous study (An et al. 2001).

Finally, we conducted a sensitivity analysis to evaluate how variable our model results were to small changes in the electricity payment effect and three key socio-demographic factors, i.e, college/technical school entrance rate, separate home intention, and max new-parental households distance, that were identified in previous studies (An et al. 2001, 2003, 2005). The sensitivity index is defined as $S x=\left(D Y / Y_{0}\right) /\left(D X / X_{0}\right)$, where $X_{0}$ is the initial value of a model parameter, $D X$ is a small change in $X, Y_{0}$ is the initial outcome, and $D Y$ is the corresponding change in $Y$ because of the change in $X$ (Haefner 1997). Small sensitivity values suggest robustness of the outcome to small changes in parameters. We also used two-sample t-tests to evaluate the magnitude of the differences in simulation results because of changes in these parameters.

\section{Simulation experiments}

We used 2006 household registration data as the starting point for the demographic submodel, 2007 land-cover data as the starting point for the landscape submodel, and ran simulations through 2030. To demonstrate the effectiveness of the NFCP and the electricity payment scenario, we also used household fuelwood use patterns prior to the NFCP (An et al. 2001) to parameterize the scenario in which no payments were provided as a comparison. We demonstrated the complex interactive effects of sociodemographic conditions and conservation policies on forest area by running simulations under different configurations of three key socio-demographic factors, i.e., college/technical school entrance rate, separate home intention, and max new-parental households distance, and distinct policy scenarios. Because of stochastic processes, the HANIP model was run 30 times using each of the parameter settings and policy scenarios to facilitate relatively robust relations between model parameters and simulation results. Results from 50 simulation runs were very similar to results from 30 simulation runs, and we report the mean values of results from 30 runs.

\section{RESULTS}

\section{Forest dynamics under different simulation experiments}

Simulations showed that forests varied under different payment scenarios over time (Fig. 3). In 2007, there were $336.82 \mathrm{~km}^{2}$ of forests in the study area. Under the baseline projection in which no payment is provided, the forest area is expected to be 233.65 $\mathrm{km}^{2}$ in 2030 . Under the cash payment of the NFCP, there are likely to be $379.47 \mathrm{~km}^{2}$ of forests in 2030 (Fig. 4). If the cash payment is replaced with an electricity payment, there are likely to be $435.00 \mathrm{~km}^{2}$ of forests in 2030 . The effects of the cash payment and the electricity payment relative to the baseline projection with no payment increase over time (Fig. 4). By 2020, there are likely to be $368.63 \mathrm{~km}^{2}$ and $406.50 \mathrm{~km}^{2}$ of forests, or an increase of 88.58 $\mathrm{km}^{2}$ and $126.45 \mathrm{~km}^{2}$ of forests to the baseline projection $(280.05$ $\mathrm{km}^{2}$ ), and by 2030 , there are likely to be an increase of $145.82 \mathrm{~km}^{2}$ and $201.34 \mathrm{~km}^{2}$ of forests to the baseline projection $\left(233.65 \mathrm{~km}^{2}\right)$ through cash payment and electricity payment, respectively. The increase in forest area is nonlinear. From 2011 to 2015 , the average yearly increase in forest area is $2.49 \mathrm{~km}^{2}$ under the cash payment, while from 2026 to 2030 the average yearly increase rate reduced to $0.91 \mathrm{~km}^{2}$. This nonlinearity occurs in response to increases in population and households. From 2006 to 2030, the model predicts increases of about $12.7 \%$ in population, to about 5075 people, and of about $26.7 \%$ in the number of households, to about 1517 households. 
Fig. 3. Distribution of forests and human residence observed in 2007 (a), and predicted changes in 2020 (b) and 2030 (c) under no-payment scenario, 2020 (d) and 2030 (e) under cash payment scenario, and 2020 (f) and 2030 (g) under electricity payment scenario. Note that these maps are made based on results from one run only, although the number of replicates is 30 for all simulation experiments.

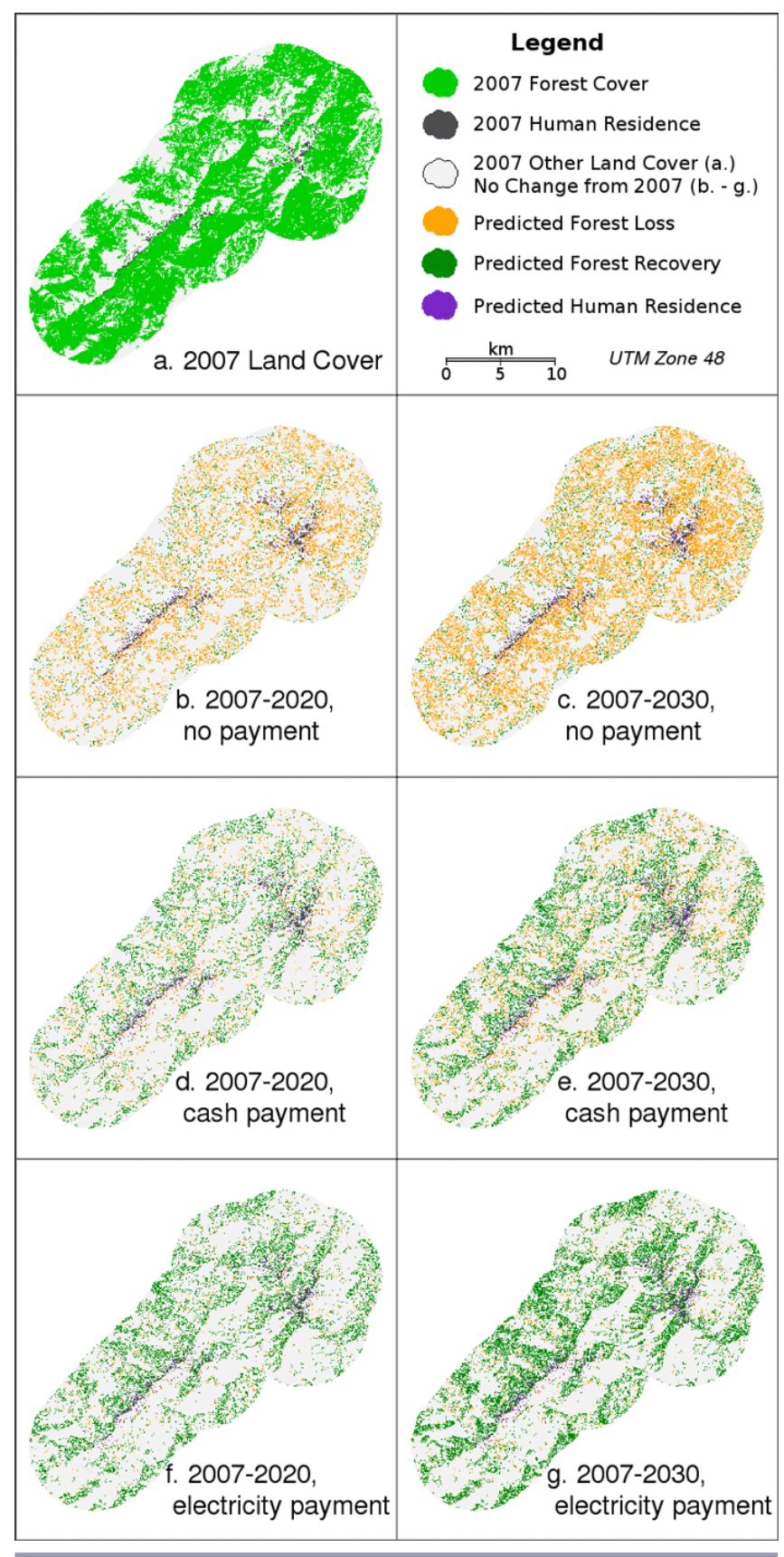

Fig. 4. Predicted forest area under cash payment, electricity payment, and no payment scenarios. We did not draw confidence intervals because standard deviations from 30 runs are small.

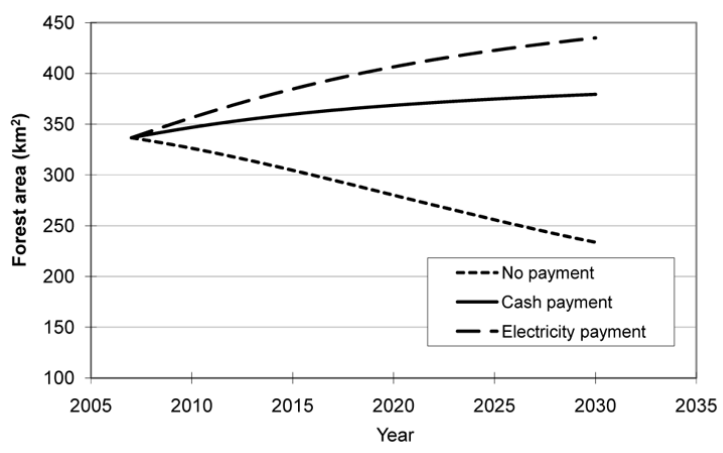

Dynamics in forests also depend on the behavior of newly formed households, i.e., households formed after 2001. The more the new households follow the fuelwood use pattern prior to the NFCP, the less forests will be gained from the conservation payment (Fig. 5). Compared to the baseline projection in which no payment is provided (Fig. 4), there are projected to be an increase of 135.12 $\mathrm{km}^{2}$ and $125.32 \mathrm{~km}^{2}$ of forests in 2030 under the cash payment of the NFCP if half and all of new households follow the fuelwood use pattern prior to the NFCP, respectively (Fig. 5). However, forest area will start decreasing by 2023 if all new households follow the fuelwood use pattern prior to the NFCP.

Fig. 5. Predicted forest area under different fuelwood use patterns followed by new households, i.e., households formed after 2001.

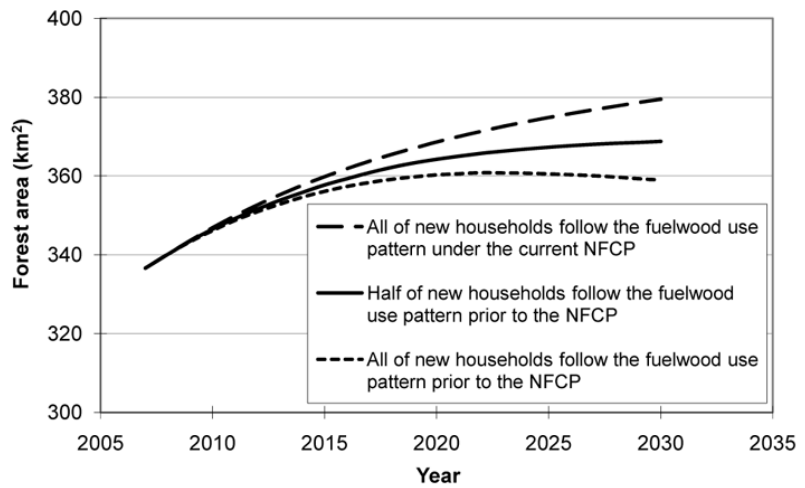

Interactive effects of three key socio-demographic factors, i.e., college/technical school entrance rate, separate home intention, and max new-parental households distance, and conservation policies on forests are shown in Figure 6. Increases in college/ technical school entrance rate, decreases in separate home intention, and decreases in max new-parental households 
Table 5. Comparison of model predictions of forest area, population size, and household number to observed values.

\begin{tabular}{lccccc}
\hline \hline Factors & Observed value & $\begin{array}{c}\text { Observed mean } \\
\text { yearly change }\end{array}$ & Model mean & $\begin{array}{c}\text { Difference between model mean } \\
\text { and observed value }\end{array}$ & $\begin{array}{c}\text { Difference|< observed mean } \\
\text { yearly change }\end{array}$ \\
\hline $\begin{array}{l}\text { Forests in 2007 } \\
\left(\mathrm{km}^{2}\right)\end{array}$ & 336.82 & 5.16 & 339.24 & 2.42 & Yes \\
Population in 2006 & 4504 & 21 & 4520 & 16 & Yes \\
Households in 2006 & 1197 & 38 & 1141 & -56 & No \\
\hline
\end{tabular}

distance will all result in increases in forests (Fig. 6). Increases in college/technical school entrance rate and decreases in separate home intention will result in reduced population size and number of households. Decreases in distances between new and parental households will reduce the possibility of converting forests to residential land and corresponding farmland because forests that were closer to households were more likely degraded or removed through previous human impacts (He et al. 2009).

The effects of these three socio-demographic factors on forests are different under different policy scenarios. A 50\% increase in college/technical school entrance rate will result in 6.56 (Fig. 6a), 4.16 (Fig. 6d), and 2.12 (Fig. 6g) km² increases in forests by 2030 under no payment, cash payment, and electricity payment, respectively. A 50\% decrease in separate home intention will result in 12.56 (Fig. 6b), 8.84 (Fig. 6e), and 4.44 (Fig. 6h) km² increases in forests by 2030 under no payment, cash payment, and electricity payment, respectively. Decreases in the effects of college/technical school entrance rate and separate home intention on forests occurred because of a reduction in per unit, i.e., person and household, fuelwood consumption when policy changes from no payment to electricity payment.

By comparison, a 50\% decrease in max new-parental households distance will result in 0.96 (Fig. 6c), 3.76 (Fig. 6f), and 2.94 (Fig. 6i) $\mathrm{km}^{2}$ increases in forests by 2030 under no payment, cash payment, and electricity payment, respectively. The effect of newparental households distance on forests was nonlinear as policy changed. This is partly because there is not much forested area around households if no payment is provided, resulting in the conversion of nonforest area into housing and farming use for many new households, and the effect of new-parental households distance will be small. The effect of new-parental households distance increased as forests recovered under cash payment. However, as forests further recover under electricity payment, many new households will be formed through the conversion of forested area, and the effect of new-parental households distance will be smaller.

\section{Results of model validation and sensitivity analysis}

Both forest loss and forest recovery models exhibited moderately high accuracy with AUC values of 0.775 and 0.773 , respectively. Comparisons of model predictions and observed values showed that predicted mean forest area in 2007 was $339.24 \mathrm{~km}^{2}$, which was close to the observed value (Table 5). The difference between the mean predicted forest area and the observed forest area was $2.42 \mathrm{~km}^{2}$, which was less than the observed mean yearly change in forests $\left(5.16 \mathrm{~km}^{2}\right)$ from 2001 to 2007 . The difference between the mean predicted human population and observed human population in 2006 was 16 , which was also less than the mean yearly population change (21) from 2000 to 2006 . The observed number of households in 2006 was 1197, 56 more than the mean predicted households. The difference in the number of households was mainly because an unexpectedly large number of new households were formed in 2001, following the implementation of the NFCP, to more effectively capture conservation subsidies that are distributed on the household basis (Liu et al. 2007a).

Sensitivity analyses (Table 6) showed that a $10 \%$ decrease in the effect of electricity payment, i.e., the average amount of fuelwood that can be saved by replacing the cash payment with an electricity payment, decreased mean forest area by $2.04 \mathrm{~km}^{2}(S x=-0.057)$. A $\mathrm{t}$-test suggested that the decrease in mean forest area was significant $(p<0.001)$. Significant decrease in mean forest area because of a decrease in the effect of electricity payment was expected because change in fuelwood use was directly related to forest dynamics in our model. Forest area was insensitive to small changes in all three socio-demographic factors (Table 6). A 10\% increase in students' college/technical school entrance rate resulted in a $0.20 \mathrm{~km}^{2}$ increase in mean forest area $(S x=0.006)$, although a $10 \%$ increase in young adult's intention of forming a new household resulted in $0.23 \mathrm{~km}^{2}$ decrease in mean forest area $(S x=-0.007)$. A $10 \%$ increase in the maximum distance between a newly formed household and its parental household decreased mean forest area by $0.17 \mathrm{~km}^{2}(S x$ $=-0.005)$. Statistical tests showed that perturbations in these parameters did not result in significant differences in mean forest area (Table 6).

\section{DISCUSSION}

Past conservation policies in Wolong Nature Reserve aimed to limit the amount and location of fuelwood collection. However, monitoring and enforcement of conservation policies were difficult (Liu et al. 2007a), resulting in rapid deforestation (Liu et al. 2001, Viña et al. 2007). Although the abrupt change in forest cover from rapid deforestation in 1994-2001 to rapid forest regeneration in 2001-2007 could arise from multiple factors, such as the improvement in electricity supply, the Natural Forest Conservation Program (NFCP) appears to have played a major role. Under this program, local households receive a significant amount of conservation payment for monitoring forest parcels. As a result, household fuelwood use has been drastically reduced. Although the NFCP has been successful in conserving forests, its effectiveness may be improved under alternative policy arrangements. In addition, there can be uncertainties in the effectiveness of such conservation investments because of complex interactions between human actions and their environmental repercussions (Liu et al. 2007a).

We developed a spatially explicit simulation model, HANIP, to study human and natural interactions under policy scenarios. Simulation experiments using HANIP enabled us to measure the effectiveness of conservation under different policies. By 2030, 
Fig. 6. Effects of socio-demographic factors on forests under no payment (a, b, c), cash payment (d, e, f), and electricity payment (g, $h$, i) scenarios.
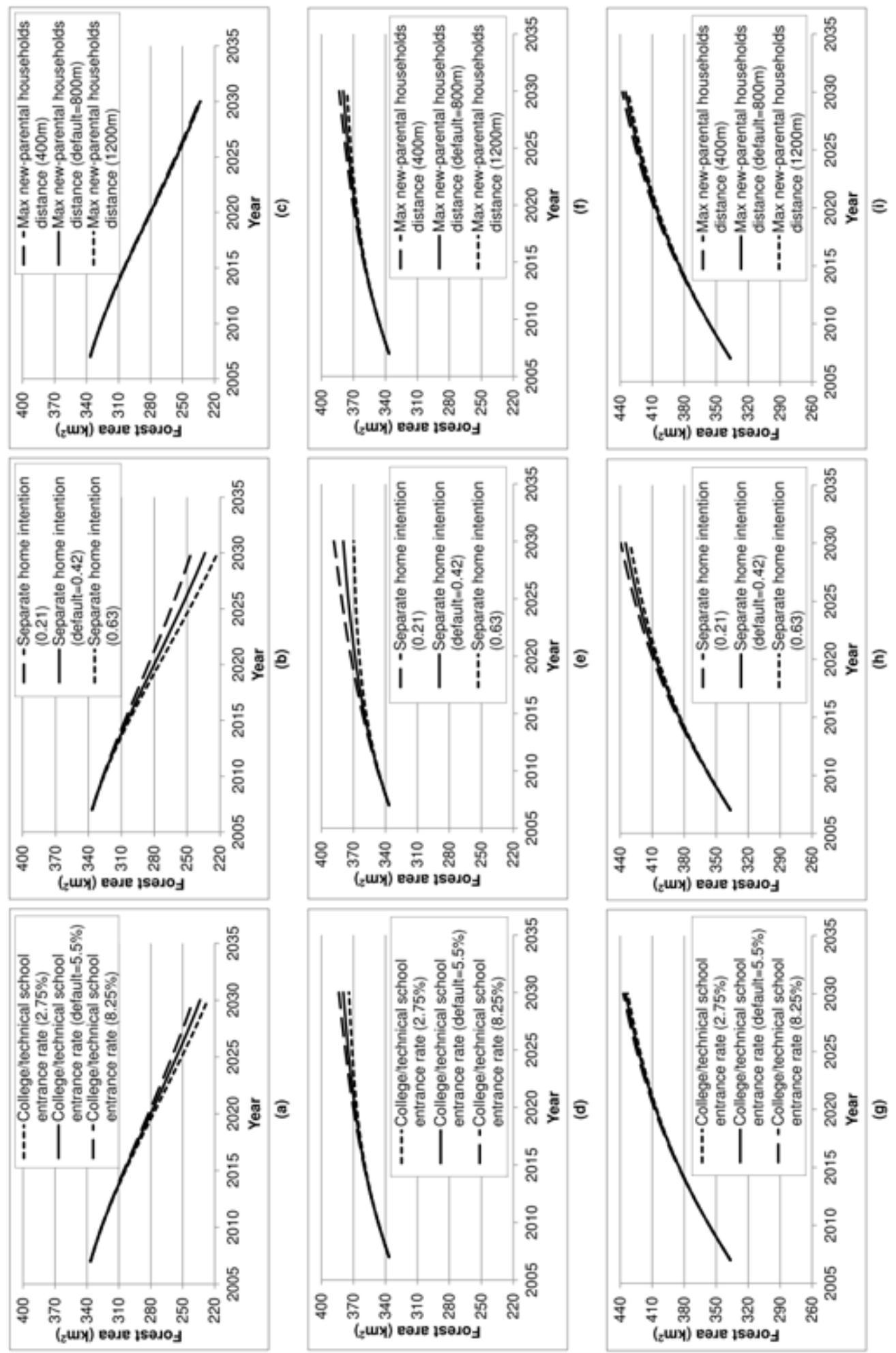
Table 6. Sensitivity tests for selected model parameters.

\begin{tabular}{|c|c|c|c|c|c|}
\hline Parameters & $\begin{array}{c}\text { Default } \\
\text { value }\end{array}$ & Perturbation & $\begin{array}{l}\text { Change in forest area } \\
\left(\mathrm{km}^{2}\right)\end{array}$ & $\begin{array}{l}\mathrm{t} \text { statistic for differences in forest } \\
\text { area (p-value) }\end{array}$ & Sensitivity \\
\hline Electricity payment effect & $3.1 \mathrm{~m}^{3}$ & $\begin{array}{l}-0.31 \\
(10 \%)\end{array}$ & -2.04 & $-11.18(<0.001)$ & -0.057 \\
\hline $\begin{array}{l}\text { College/technical school } \\
\text { entrance rate }\end{array}$ & 0.055 & $\begin{array}{c}+0.0055 \\
(10 \%)\end{array}$ & 0.20 & $1.22(0.231)$ & 0.006 \\
\hline Separate home intention & 0.42 & $\begin{array}{r}+0.042 \\
(10 \%)\end{array}$ & -0.23 & $-1.61(0.119)$ & -0.007 \\
\hline $\begin{array}{l}\text { Max new-parental } \\
\text { households distance }\end{array}$ & $800 \mathrm{~m}$ & $\begin{array}{c}+80 \\
(10 \%)\end{array}$ & -0.17 & $-0.87(0.391)$ & -0.005 \\
\hline
\end{tabular}

145.82 and $201.34 \mathrm{~km}^{2}$ of forests in the study area can be gained through prevented deforestation and forest recovery using cash payment and electricity payment mechanisms, respectively. Compared to cash payment, conservation payment in the form of electricity is a more direct approach of paying people to reduce their negative impacts by replacing fuelwood with electricity. Therefore, electricity payment may improve the efficiency of conservation investments, which is important as current conservation investments are far below the requirements for conserving ecosystems globally (James et al. 1999, 2001). We recognize that there are potential negative environmental impacts from electricity generation, such as landslides, water and air pollution, greenhouse gas emissions, soil erosion, and biodiversity losses (Liu and Diamond 2005), which should also be considered for policy implementation.

Through modeling dynamics of population and households, HANIP can also detect changes in the impacts of policy interventions on forests over time. Nonlinear increases in forests under policy interventions suggested that conservation gains from PES programs may largely depend on population and household dynamics in indigenous communities. The effectiveness of conservation investments may not be sustainable because of uncertain human responses to policy interventions. Similar fuelwood use between NFCP participating households and new households reflected the increased forest monitoring and potential normative effects. As the number of newly formed households increases, the effectiveness of conservation payment may be threatened by the behavior of new households if they are not included in the program.

We also explored the effects of socio-demographic factors on forests by using three different values for each of three key sociodemographic factors. We found that the effects of these sociodemographic factors on forests differed under different policy scenarios, suggesting the presence of interactive effects of policy interventions and socio-demographic factors on forests. In the real world, however, these factors may not be constant over 20 years. Long-term research in this area may provide information about changes in these factors that can be used to further explain the impacts of dynamic socio-demographic conditions on forests.

As forests recover through conservation payments, the habitat of many wildlife species may be restored. However, the effects of conservation policy implementation on wildlife habitat may lag behind because it usually takes a few decades for the habitat of wildlife species, such as the giant pandas, to fully recover after forest recovery (Bearer et al. 2008). This suggests that conservation investments should be continued for relatively long periods of time to restore the habitat of wildlife species.

In the parameterization of HANIP, we approximated the effects of conservation policies by comparing the fuelwood use under the current NFCP payment and under an alternative electricity payment to the fuelwood use prior to the NFCP. Although many factors may have contributed to the fuelwood use and its corresponding dynamics in forests, field observations suggest that the NFCP has played a major role in forest dynamics in Wolong. Accurate evaluation of conservation policies requires the comparison of outcomes between treatment groups, i.e., areas in which policies are implemented, with control groups, i.e., areas in which policies are not implemented, through advanced program evaluation approaches such as propensity score matching (Ferraro and Pattanayak 2006, Alix-Garcia et al. 2008, Andam et al. 2008, Joppa and Pfaff 2011, Arriagada et al. 2012, Chen et al. 2012b). Future studies on the evaluation of the NFCP may compare forest dynamics between Wolong and its neighboring areas in which the NFCP may not have been fully implemented.

Because demographic information in 2006 was not used in the calibration of the demographic submodel, validation of the demographic submodel was conducted by comparing population size and the number of households between simulated and observed values in 2006. For the landscape submodel, forest cover change between 1994 and 2001 was used to characterize dynamics in forest cover prior to the NFCP implementation, and forest cover change between 2001 and 2007 was used to characterize dynamics in forest cover after the implementation of the NFCP. Because forest cover data in 1994, 2001, and 2007 were all used for model calibration, we used a receiver operating characteristics (ROC) curve to evaluate the regression models for forest loss and recovery. As independent forest cover data become available, further validation of the landscape submodel at the pixel level based on approaches such as those developed by Pontius and coauthors (Pontius and Pacheco 2004, Pontius et al. 2004, Pontius and Malanson 2005) can be helpful. In addition, classification errors of forest cover in 1994, 2001, and 2007 may compromise the performance of the model at the pixel level, but are unlikely to have significant impact on the magnitude of policy effects because classification errors were random rather than systematic, thus unlikely to be biased.

Interactions among components in coupled human and natural systems (CHANS) are complex (Liu et al. 2007a). Accurate 
prediction of these interactions is difficult. For instance, our model for estimating household fuelwood consumption (Table 1) does not have a high prediction power, although the variables on the basis of the estimated fuelwood consumption from this model were significant predictors in forest loss/recovery models (Tables $3,4)$, which have moderate levels of prediction power. Therefore, like all other models, our model (HANIP) is a simplified representation of human-nature interactions under policies in the real world. Nevertheless, modeling some of the key dynamic interactions using HANIP is important for understanding the long-term effectiveness of conservation investments that may involve complexity, e.g., nonlinearity, and uncertainty. The modeling framework of HANIP may also be used to study the dynamics of key interactions, as well as long-term effectiveness of conservation policies in many other coupled human-nature systems around the world.

Responses to this article can be read online at: http://www.ecologyandsociety.org/issues/responses. $\mathrm{php} / 5578$

\section{Acknowledgments:}

We thank Mingchong Liu, Shiqiang Zhou, Jinyan Huang, Weihong Tan, Jian Yang, Yingchun Tan, Xiaoping Zhou, Hemin Zhang, and Zhiyun Ouyang for their help during fieldwork. We thank the editor and two anonymous reviewers for their constructive criticisms on an earlier draft of this paper. We gratefully acknowledge financial support from NSF, NASA, NIH, and MSU Ag-Bio Research.

\section{LITERATURE CITED}

Alix-Garcia, J., A. De Janvry, and E. Sadoulet. 2008. The role of deforestation risk and calibrated compensation in designing payments for environmental services. Environment and Development Economics 13:375-394.

An, L., M. Linderman, J. Qi, A. Shortridge, and J. Liu. 2005. Exploring complexity in a human-environment system: an agentbased spatial model for multidisciplinary and multiscale integration. Annals of the Association of American Geographers 95:54-79. http://dx.doi.org/10.1111/j.1467-8306.2005.00450.x

An, L., and J. Liu. 2010. Long-term effects of family planning and other determinants of fertility on population and environment: agent-based modeling evidence from Wolong Nature Reserve, China. Population and Environment 31:427-459. http://dx.doi.org/10.1007/s11111-010-0111-3

An, L., J. Liu, Z. Ouyang, M. Linderman, S. Zhou, and H. Zhang. 2001. Simulating demographic and socioeconomic processes on household level and implications for giant panda habitats. Ecological Modelling 140:31-49. http://dx.doi.org/10.1016/ $\underline{\text { S0304-3800(01)00267-8 }}$

An, L., F. Lupi, J. Liu, M. Linderman, and J. Huang. 2002. Modeling the choice to switch from fuelwood to electricity: implications for giant panda habitat conservation. Ecological Economics 42:445-457. http://dx.doi.org/10.1016/S0921-8009(02) 00126-X
An, L., A. G. Mertig, and J. Liu. 2003. Adolescents leaving parental home: psychosocial correlates and implications for conservation. Population and Environment 24:415-444. http://dx. doi.org/10.1023/A:1023694924954

Andam, K. S., P. J. Ferraro, A. Pfaff, G. A. Sanchez-Azofeifa, and J. A. Robalino. 2008. Measuring the effectiveness of protected area networks in reducing deforestation. Proceedings of the National Academy of Sciences 105:16089-16094. http://dx.doi. org/10.1073/pnas.0800437105

Arriagada, R. A., P. J. Ferraro, E. O. Sills, S. K. Pattanayak, and S. Cordero-Sancho. 2012. Do payments for environmental services affect forest cover? A farm-level evaluation from Costa Rica. Land Economics 88:382-399.

Arthur, W. B. 1999. Complexity and the economy. Science 284:107-109. http://dx.doi.org/10.1126/science.284.5411.107

Asquith, N. M., M. T. Vargas, and S. Wunder. 2008. Selling two environmental services: in-kind payments for bird habitat and watershed protection in Los Negros, Bolivia. Ecological Economics 65:675-684. http://dx.doi.org/10.1016/j.ecolecon.2007.12.014

Axelrod, R., and M. D. Cohen. 1999. Harnessing complexity: organizational implications of a scientific frontier. Free Press, New York, New York, USA.

Bearer, S., M. Linderman, J. Huang, L. An, G. He, and J. Liu. 2008. Effects of fuelwood collection and timber harvesting on giant panda habitat use. Biological Conservation 141:385-393. http://dx.doi.org/10.1016/j.biocon.2007.10.009

Chen, X., K. A. Frank, T. Dietz, and J. Liu. 2012b. Weak ties, labor migration, and environmental impacts: toward a sociology of sustainability. Organization and Environment 25:3-24. http:// dx.doi.org/10.1177/1086026611436216

Chen, X., F. Lupi, L. An, R. Sheely, A. Viña, and J. Liu. $2012 a$. Agent-based modeling of the effects of social norms on enrollment in payments for ecosystem services. Ecological Modelling 229:16-24. http://dx.doi.org/10.1016/j.ecolmodel.2011.06.007

Chen, X., F. Lupi, G. He, and J. Liu. 2009. Linking social norms to efficient conservation investment in payments for ecosystem services. Proceedings of the National Academy of Sciences 106:11812-11817. http://dx.doi.org/10.1073/pnas.0809980106

Chen, X., F. Lupi, A. Viña, G. He, and J. Liu. 2010. Using costeffective targeting to enhance the efficiency of conservation investments in payments for ecosystem services. Conservation Biology 24:1469-1478. http://dx.doi.org/10.1111/j.1523-1739.2010.01551. $\underline{x}$

Crawford, T. W., J. P. Messina, S. M. Manson, and D. O'Sullivan. 2005. Complexity science, complex systems, and land-use research. Environment and Planning B-Planning and Design 32:792-798. http://dx.doi.org/10.1068/b3206ed

Cullen, R., G. A. Fairburn, and K. F. D. Hughey. 2001. Measuring the productivity of threatened-species programs. Ecological Economics 39:53-66. http://dx.doi.org/10.1016/S0921-8009(01) 00191-4

Curran, L. M., S. N. Trigg, A. K. McDonald, D. Astiani, Y. M. Hardiono, P. Siregar, I. Caniago, and E. Kasischke. 2004. 
Lowland forest loss in protected areas of Indonesian Borneo. Science 303:1000-1003. http://dx.doi.org/10.1126/science.1091714

Deadman, P., D. Robinson, E. Moran, and E. Brondizio. 2004. Colonist household decisionmaking and land-use change in the Amazon Rainforest: an agent-based simulation. Environment and Planning B-Planning and Design 31:693-709. http://dx.doi. org/10.1068/b3098

Dunn, C. P., F. Stearns, G. R. Guntenspergen, and D. M. Sharpe. 1993. Ecological benefits of the Conservation Reserve Program. Conservation Biology 7:132-139. http://dx.doi.org/10.1046/ j.1523-1739.1993.07010132.x

Ferraro, P. J., and A. Kiss. 2002. Direct payments to conserve biodiversity. Science 298:1718-1719. http://dx.doi.org/10.1126/ science.1078104

Ferraro, P. J., and S. K. Pattanayak. 2006. Money for nothing? A call for empirical evaluation of biodiversity conservation investments. PLOS Biology 4:482-488. http://dx.doi.org/10.1371/ journal.pbio.0040105

Foley, J. A., R. DeFries, G. P. Asner, C. Barford, G. Bonan, S. R. Carpenter, F. S. Chapin, M. T. Coe, G. C. Daily, H. K. Gibbs, J. H. Helkowski, T. Holloway, E. A. Howard, C. J. Kucharik, C. Monfreda, J. A. Patz, I. C. Prentice, N. Ramankutty, and P. K. Snyder. 2005. Global consequences of land use. Science 309:570-574. http://dx.doi.org/10.1126/science.1111772

Geoghegan, J., S. C. Villar, P. Klepeis, P. M. Mendoza, Y. OgnevaHimmelberger, R. R. Chowdhury, B. L. Turner, II, and C. Vance. 2001. Modeling tropical deforestation in the southern Yucatán peninsular region: comparing survey and satellite data. Agriculture, Ecosystems and Environment 85:25-46. http://dx.doi. org/10.1016/S0167-8809(01)00201-8

Goldstein, N. J., R. B. Cialdini, and V. Griskevicius. 2008. A room with a viewpoint: using social norms to motivate environmental conservation in hotels. Journal of Consumer Research 35:472-482. http://dx.doi.org/10.1086/586910

Haefner, J. W. 1997. Modeling biological systems: principles and applications. Chapman and Hall, New York, New York, USA.

Hanley, J. A., and B. J. Mcneil. 1982. The meaning and use of the area under a receiver operating characteristic (ROC) curve. Radiology 143:29-36.

He, G. 2008. Balancing human energy needs and conservation of panda habitat. Dissertation. Michigan State University, East Lansing, Michigan, USA.

He, G., X. Chen, W. Liu, S. Bearer, S. Zhou, L. Cheng, H. Zhang, Z. Ouyang, and J. Liu. 2008. Distribution of economic benefits from ecotourism: a case study of Wolong Nature Reserve for Giant Pandas in China. Environmental Management 42:1017-1025. http://dx.doi.org/10.1007/s00267-008-9214-3

He, G., X. Chen, S. Bearer, M. Colunga, A. Mertig, L. An, S. Zhou, M. Linderman, Z. Ouyang, S. Gage, S. Li, and J. Liu. 2009. Spatial and temporal patterns of fuelwood collection in Wolong Nature Reserve: implications for panda conservation. Landscape and Urban Planning 92:1-9. http://dx.doi.org/10.1016/j. landurbplan.2009.01.010

James, A. N., K. J. Gaston, and A. Balmford. 1999. Balancing the Earth's accounts. Nature 401:323-324. http://dx.doi.org/10.1038/43774
James, A. N., K. J. Gaston, and A. Balmford. 2001. Can we afford to conserve biodiversity? Bioscience 51:43-52. http://dx.doi. org/10.1641/0006-3568(2001)051[0043:CWATCB]2.0.CO;2

Jensen, J. R. 1996. Introductory digital image processing, a remote sensing perspective. Second edition. Prentice Hall, Upper Saddle River, New Jersey, USA.

Johnson, D. H., and M. D. Schwartz. 1993. The Conservation Reserve Program and grassland birds. Conservation Biology 7:934-937. http://dx.doi.org/10.1046/j.1523-1739.1993.740934.x

Joppa, L. N., and A. Pfaff. 2011. Global protected area impacts. Proceedings of the Royal Society B-Biological Sciences 278:1633-1638. http://dx.doi.org/10.1098/rspb.2010.1713

Linderman, M., L. An, S. Bearer, G. He, Z. Ouyang, and J. Liu. 2005. Modeling the spatio-temporal dynamics and interactions of households, landscapes, and giant panda habitat. Ecological Modelling 183:47-65. http://dx.doi.org/10.1016/j.ecolmodel.2004.07.026

Liu, J. 2010. China's road to sustainability. Science 328:50. http:// dx.doi.org/10.1126/science.1186234

Liu, J., G. C. Daily, P. R. Ehrlich, and G. W. Luck. 2003. Effects of household dynamics on resource consumption and biodiversity. Nature 421:530-533. http://dx.doi.org/10.1038/nature01359

Liu, J., and J. Diamond. 2005. China's environment in a globalizing world. Nature 435:1179-1186. http://dx.doi.org/10.1038/4351179a

Liu, J., T. Dietz, S. R. Carpenter, M. Alberti, C. Folke, E. Moran, A. N. Pell, P. Deadman, T. Kratz, J. Lubchenco, E. Ostrom, Z. Ouyang, W. Provencher, C. L. Redman, S. H. Schneider, and W. W. Taylor. 2007a. Complexity of coupled human and natural systems. Science 317:1513-1516. http://dx.doi.org/10.1126/science.1144004

Liu, J., T. Dietz, S. R. Carpenter, C. Folke, M. Alberti, C. L. Redman, S. H. Schneider, E. Ostrom, A. N. Pell, J. Lubchenco, W. W. Taylor, Z. Ouyang, P. Deadman, T. Kratz, and W. Provencher. 2007b. Coupled human and natural systems. Ambio 36:639-649. http://dx.doi.org/10.1579/0044-7447(2007)36[639:CHANS]2.0.CO;2

Liu, J., V. Hull, M. Batistella, R. DeFries, T. Dietz, F. Fu, T. W. Hertel, R. C. Izaurralde, E. F. Lambin, S. Li, L. A. Martinelli, W. J. McConnell, E. F. Moran, R. Naylor, Z. Ouyang, K. R. Polenske, A. Reenberg, G. de Miranda Rocha, C. S. Simmons, P. H. Verburg, P. M. Vitousek, F. Zhang, and C. Zhu. 2013. Framing sustainability in a telecoupled world. Ecology and Society 18(2): 26. http://dx.doi. org/10.5751/ES-05873-180226

Liu, J., S. Li, Z. Ouyang, C. Tam, and X. Chen. 2008. Ecological and socioeconomic effects of China's policies for ecosystem services. Proceedings of the National Academy of Sciences 105:9477-9482. http://dx.doi.org/10.1073/pnas.0706436105

Liu, J., M. Linderman, Z. Ouyang, L. An, J. Yang, and H. Zhang. 2001. Ecological degradation in protected areas: the case of Wolong Nature Reserve for giant pandas. Science 292:98-101. http://dx.doi. org/10.1126/science.1058104

Liu, J., and P. H. Raven. 2010. China's environmental challenges and implications for the world. Critical Reviews in Environmental Science and Technology 40:823-851. http://dx.doi. org/10.1080/10643389.2010.502645

Loucks, C. J., Z. Lü, E. Dinerstein, H. Wang, D. M. Olson, C. Zhu, and D. Wang. 2001. Giant pandas in a changing landscape. Science 294:1465. http://dx.doi.org/10.1126/science. 1064710 
Luck, G. W., T. H. Ricketts, G. C. Daily, and M. Imhoff. 2004. Alleviating spatial conflict between people and biodiversity. Proceedings of the National Academy of Sciences 101:182-186. http://dx.doi.org/10.1073/pnas.2237148100

Malanson, G. P., Y. Zeng, and S. J. Walsh. 2006. Complexity at advancing ecotones and frontiers. Environment and Planning $A$ 38:619-632. http://dx.doi.org/10.1068/a37340

Manson, S. M., and T. Evans. 2007. Agent-based modeling of deforestation in southern Yucatan, Mexico, and reforestation in the Midwest United States. Proceedings of the National Academy of Sciences 104:20678-20683. http://dx.doi.org/10.1073/pnas.0705802104

Matthews, R. B., N. G. Gilbert, A. Roach, J. G. Polhill, and N. M. Gotts. 2007. Agent-based land-use models: a review of applications. Landscape Ecology 22:1447-1459. http://dx.doi. org/10.1007/s10980-007-9135-1

McMaster, D. G., and S. K. Davis. 2001. An evaluation of Canada's Permanent Cover Program: habitat for grassland birds? Journal of Field Ornithology 72:195-210.

Millennium Ecosystem Assessment (MEA). 2005. Ecosystems and human well-being. Island, Washington, D.C., USA.

Myers, N., R. A. Mittermeier, C. G. Mittermeier, G. A. B. da Fonseca, and J. Kent. 2000. Biodiversity hotspots for conservation priorities. Nature 403:853-858. http://dx.doi.org/10.1038/35002501

Nagendra, H., J. Southworth, and C. Tucker. 2003. Accessibility as a determinant of landscape transformation in western Honduras: linking pattern and process. Landscape Ecology 18:141-158. http://dx.doi.org/10.1023/A:1024430026953

Organisation for Economic Co-operation and Development (OECD). 1997. The environmental effects of agricultural land diversion schemes. Organisation for Economic Co-operation and Development, Paris, France.

Osborn, T., S. Brownback, and M. Schamberger. 1993. The Conservation Reserve Program - status, future, and policy options. Journal of Soil and Water Conservation 48:271-279.

Ostrom, E. 2009. A general framework for analyzing sustainability of social-ecological systems. Science 325:419-422. http://dx.doi.org/10.1126/science.1172133

Parker, A. J. 1982. The topographic relative moisture index: an approach to soil-moisture assessment in mountain terrain. Physical Geography 3:160-168.

Parker, D. C., S. M. Manson, M. A. Janssen, M. J. Hoffmann, and P. Deadman. 2003. Multi-agent systems for the simulation of land-use and land-cover change: a review. Annals of the Association of American Geographers 93:314-337. http://dx.doi. org/10.1111/1467-8306.9302004

Pontius, Jr., G. R., and J. Malanson. 2005. Comparison of the structure and accuracy of two land change models. International Journal of Geographical Information Science 19:243-265. http:// dx.doi.org/10.1080/13658810410001713434

Pontius, Jr., G. R., and P. Pacheco. 2004. Calibration and validation of a model of forest disturbance in the Western Ghats, India 1920-1990. GeoJournal 61:325-334. http://dx.doi. org/10.1007/s10708-004-5049-5
Pontius, Jr., G. R., D. Huffaker, and K. Denman. 2004. Useful techniques of validation for spatially explicit land-change models. Ecological Modelling 179:445-461. http://dx.doi.org/10.1016/j. ecolmodel.2004.05.010

Rosa, E. A., and T. Dietz. 1998. Climate change and society speculation, construction and scientific investigation. International Sociology 13:421-455. http://dx.doi.org/10.1177/026858098013004002

Salafsky, N., and R. Margoluis. 1999. Threat reduction assessment: a practical and cost-effective approach to evaluating conservation and development projects. Conservation Biology 13:830-841. http://dx.doi.org/10.1046/j.1523-1739.1999.98183.x

Sierra, R., and E. Russman. 2006. On the efficiency of environmental service payments: a forest conservation assessment in the Osa Peninsula, Costa Rica. Ecological Economics 59:131-141. http://dx.doi.org/10.1016/j.ecolecon.2005.10.010

Siikamäki, J., and D. F. Layton. 2007. Potential cost-effectiveness of incentive payment programs for the protection of nonindustrial private forests. Land Economics 83:539-560.

Smith, R. B. W. 1995. The Conservation Reserve Program as a least-cost land retirement mechanism. American Journal of Agricultural Economics 77:93-105. http://dx.doi.org/10.2307/1243892

Turner, II, B. L., E. F. Lambin, and A. Reenberg. 2007. The emergence of land change science for global environmental change and sustainability. Proceedings of the National Academy of Sciences 104:20666-20671. http://dx.doi.org/10.1073/pnas.0704119104

Viña, A., S. Bearer, X. Chen, G. He, M. Linderman, L. An, H. Zhang, Z. Ouyang, and J. Liu. 2007. Temporal changes in giant panda habitat connectivity across boundaries of Wolong Nature Reserve, China. Ecological Applications 17:1019-1030. http://dx. doi.org/10.1890/05-1288

Viña, A., X. Chen, W. J. McConnell, W. Liu, W. Xu, Z. Ouyang, H. Zhang, and J. Liu. 2011. Effects of natural disasters on conservation policies: the case of the 2008 Wenchuan earthquake, China. Ambio 40:274-284. http://dx.doi.org/10.1007/s13280-010-0098-0

Von Bertalanffy, L. 1968. General system theory: foundations, development, applications. George Braziller, New York, New York, USA.

Wackernagel, M., N. B. Schulz, D. Deumling, A. C. Linares, M. Jenkins, V. Kapos, C. Monfreda, J. Loh, N. Myers, R. Norgaard, and J. Randers. 2002. Tracking the ecological overshoot of the human economy. Proceedings of the National Academy of Sciences 99:9266-9271. http://dx.doi.org/10.1073/pnas.142033699

Walsh, S. J., J. P. Messina, C. F. Mena, G. P. Malanson, and P. H. Page. 2008. Complexity theory, spatial simulation models, and land use dynamics in the northern Ecuadorian Amazon. Geoforum 39:867-878. http://dx.doi.org/10.1016/j.geoforum.2007.02.011

Warren, K., C. Franklin, and C. L. Streeter. 1998. New directions in systems theory: chaos and complexity. Social Work 43:357-372. http://dx.doi.org/10.1093/sw/43.4.357

Wolong Nature Reserve. 2000. Compilation of codes and regulations in Wolong (in Chinese). Wolong Nature Reserve, Wenchuan County, Sichuan Province, People's Republic of China. 
Wooldridge, J. M. 2002. Econometric analysis of cross section and panel data. MIT Press, Cambridge, Massachusetts, USA.

World Bank. 2001. China: air, land, and water: environmental priorities for a new millennium. World Bank, Washington, D.C., USA.

Wunder, S. 2007. The efficiency of payments for environmental services in tropical conservation. Conservation Biology 21:48-58. http://dx.doi.org/10.1111/j.1523-1739.2006.00559.x

Wunder, S. 2008. Payments for environmental services and the poor: concepts and preliminary evidence. Environment and Development Economics 13:279-297. http://dx.doi.org/10.1017/ $\underline{\mathrm{S} 1355770 \mathrm{X} 08004282}$

Xu, J., R. Yin, Z. Li, and C. Liu. 2006a. China's ecological rehabilitation: unprecedented efforts, dramatic impacts, and requisite policies. Ecological Economics 57:595-607. http://dx.doi. org/10.1016/j.ecolecon.2005.05.008

Xu, W., Z. Ouyang, A. Viña, H. Zheng, J. Liu, and Y. Xiao. 2006 b. Designing a conservation plan for protecting the habitat for the Giant Pandas in the Qionglai Mountain Range, China. Biodiversity and Distributions 12(5):610-619.

Yang, W., W. Liu, A.Viña, M. Tuanmu, G. He, T. Dietz, and J. Liu. 2013. Nonlinear effects of group size on collective action and resource outcomes. Proceedings of the National Academy of Sciences 110:10916-10921. http://dx.doi.org/10.1073/pnas.1301733110

Zbinden, S., and D. R. Lee. 2005. Paying for environmental services: an analysis of participation in Costa Rica's PSA program. World Development 33:255-272. http://dx.doi. org/10.1016/j.worlddev.2004.07.012

Zuo, T. 2002. Implementation of the NFPP. Pages 3-14 in J. Xu., E. Katsigris., and T. A. White, editors. Implementing the Natural Forest Protection Program and the Sloping Land Conversion Program: lessons and policy recommendations. China Forestry Publishing House, Beijing, China. 